\title{
Migration and Transformation of Phosphorus Forms in Field Ditch Sediments
}

\author{
Aiping Tang ${ }^{1,2}$, Rong Wang ${ }^{3}$, and Jinbao Wan ${ }^{*}, 1$ \\ ${ }^{I}$ The Key Lab. Of Poyang Lake Environment and Resource Utilization, School of Environment and Chemical \\ Engineering, Nanchang University, Nanchang 330031, China \\ ${ }^{2}$ School of Resources, Environmental \& Chemical Engineering, Key Laboratory of Jiangxi Province for Ecological \\ Diagnosis-Remediation and Pollution Control, Nanchang Hang Kong University, Nanchang 330063, China \\ ${ }^{3}$ College of Land Resources and Environment, Jiangxi Agriculture University, Nanchang 330045, China
}

\begin{abstract}
A broad attention has been paid to the field ditches as the sewage interception channel for the agricultural nonpoint source pollution, however, rare studies have involved in the phosphorus migration and transformation between the ditch sediments and overlaying water, especially, from the ditch sediments to the water. The present paper aims to explore with XPS binding energy data how $\mathrm{pH}$, dissolved oxygen, sunlight affect the process of phosphorus migration and transformation in ditch sediments to the water by methods of changing $\mathrm{pH}$, aerating nitrogen and oxygen in water and changing the sunlight; and hopes to provide a guidance on how to give full play to the ditch's sewage interception capacity and avoid ditch becoming pollution source reversely. The experimental results with XPS binding energy data show that no electron transfer occurs insignificantly at different $\mathrm{pH}$ values in sediments, i.e. no electron transfer reaction occurs on surface. This reveals that the phosphorus absorption form $\mathrm{HPO}_{4}{ }^{2-}$ in sediment substitutes $\mathrm{OH}^{-}$state on the sediment surface. The amount of phosphorus migration and transformation is the minimum under the neutral condition, and the maximum under the alkaline condition. Under aerobic atmosphere, the data of XPS binding energy shows the surface charge of iron after oxygen aeration reduces, the surface charge of oxygen increases, i.e. $\mathrm{Fe}^{2+}$ is oxidized into $\mathrm{Fe}^{3+}$, the phosphorus is absorbed increasingly; the experimental results with XPS binding energy data disclose there exists electron transfer reaction significantly, that is the illumination affects the process of phosphorus migration and transformation through dissolved oxygen (DO) and the $\mathrm{pH}$ impacted on the biological processes under the presence of sunlight in sediments, indirectly. The influence of illumination on the sediment phosphorus migration and transformation is regular insignificantly. Conclusively, the amount of migration and transformation in sunlight-free group is greater than the sunlight group.
\end{abstract}

Keywords: Dissolved oxygen, ditch sediments, light intensity, migration and transformation, pH, phosphorus fraction, XPS.

\section{INTRODUCTION}

Over-fertilization during the agricultural production causes a large number of nutrients enter the rivers and lake via drainage or runoff, directly resulting in water eutrophication. Poyang Lake region is the main producing areas of double cropping of rice in Jiangxi [1]. Although the absorption rate did not improve (the absorption rate of phosphate fertilizer does not exceed 35\%) [2], the unit fertilizer applied has increased year by year. According to statistics, Jiangxi Province had the average farmland fertilizer $355.8 \mathrm{~kg} / \mathrm{hm}^{2}$ in 1990 , which reached $623.4 \mathrm{~kg} / \mathrm{hm}^{2}$ in 2006 with an increase of $75.2 \%$. The resultant agricultural nonpoint source pollutants were flushed into the rivers along with drainage and precipitation through field ditches, and finally rushed to Poyang Lake and affected the lake water quality. As a primary sewage interception channel in agricultural nonpoint source pollution control pathway, the ecological ditches have been investigated by many researchers [3-8] on their ability to intercept the nutrients. The research findings showed that the ditch sediments have a stronger nutrient-removing ability. However, due to seasonal field drainage, the ditches especially the traditional ones can increase the phosphorus content in sediments in a period. Owing to shallow water and sunlight penetration to bottom, the diurnal dissolved oxygen concentration and $\mathrm{pH}$ varies significantly [9-11]. With the change in oxygen concentration, illumination and other external environmental factors, the transformation and decomposition of accumulated organic matters and nutrients in the sediments will be speeded up [12] so that the phosphorus absorbed, precipitated and carried in the ditch sediments is resolved and entered the downstream water, thus increasing the risk of eutrophication. A majority of present studies have explored the nutrient removal ability of ecological ditch sediments and phosphorus release process in lake sediments. Rare studies have discussed the phosphorus migration and transformation rule of the ecological ditches. The present selects the ecological ditch sediments from a small basin in Qiaoxiali 
Villa, Bailu Town, Xingzi county in Poyang Lake basin as a demonstrative area to examine the effect of $\mathrm{pH}$, dissolved oxygen, and light intensity on migration and transformation of phosphorus forms decided by graded extraction method and combine with XPS binding energy data, hopes to find a nutrient transformation rules of the ecological ditches, fully utilizes the sewage interception ability of ecological ditches in Poyang Lake area, reduces the nutrients that enter the lake and finally reduces the risk of eutrophication in Poyang Lake.

\section{DEMONSTRATIVE EXPERIMENTAL AREA}

The demonstrative area in the study is less than $2.3 \mathrm{~km}$ away from Poyang Lake in the straight-line distance based on the traditional planting mainly, covers an agricultural area about two hectares, mainly includes rice fields, vegetable (peanuts, beans, sweet potato) field and a few of wastelands. The average fertilizer applied per mu is $401 \mathrm{~kg}$. The soil is Quaternary red soil. The field ditches are crisscrossed in the region and become the primary channel for the field drainage and rainfall runoff. After the convergence, the water goes into Poyang Lake via the downstream rivers. Within ditches, the depth is $40-50 \mathrm{~cm}$, the overall water flow rate is smooth, $20-30 \mathrm{~cm}$-thick mud is accumulated in the ditch bottom and a small amount of emergent aquatic plants are dotted.

\section{MATERIALS AND METHODOLOGY}

\subsection{Sample Collection and Analysis for the Test}

Sediments in 6 sampling points were selected from the demonstrative farmland ditches (see Fig. 1). The sediments (mainly from the soil carried by runoff in farmland and from the suspension caused by the ditch water flowing) were gathered using cylindrical sampler, sealed, crushed, dried, ground, and screened by 16-mesh for use purpose in laboratory.

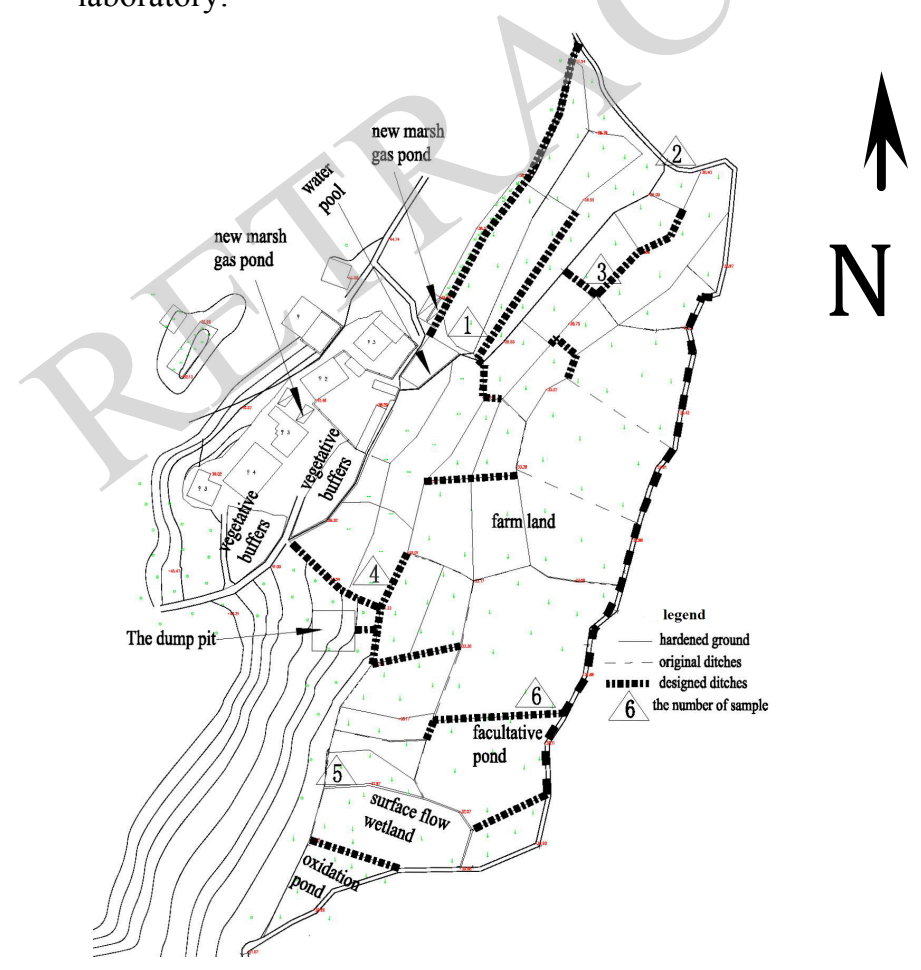

Fig. (1). Sampling location.
The ditch water $\mathrm{pH}$ was measured $6 \sim 9$ on site, the ditch sediment $\mathrm{pH}$ was measured 5.8 7.2, and the dissolved oxygen (DO) was measured $4.2 \sim 8.9 \mathrm{mg} / \mathrm{L}$ on site. With ASTM classification method [13], and the Mastersizer 2000 laser particle size analyzer, the particle distribution was measured: claye particle $(<4 \mu \mathrm{m}) 9.6 \%$, silt particle $(4 \sim 63$ $\mu \mathrm{m}) 74.9 \%$, sand particle $(63 \sim 2000 \mu \mathrm{m}) 15.5 \%$.

\subsection{Analysis Items and Analysis Method}

\subsubsection{Overlying Water}

The analysis items included the dissolved total phosphorus (DTP), $\mathrm{pH}$, dissolved oxygen (DO), etc. in the overlying water and all items were measured in line with the Monitoring and Analysis Method for Water and Wastewater (the $4^{\text {th }}$ edition).

\subsubsection{Sediments}

The phosphorus forms in the sediments were decided by Specification for Lake Eutrophication Survey (the $2^{\text {nd }}$ edition) and SMT [14] (graded extraction method). After determination, the sediment background values are $\mathrm{NaOH}-\mathrm{P}$ $57.76 \mathrm{mg} / \mathrm{kg}$, HCl-P $6.01 \mathrm{mg} / \mathrm{kg}$, IP $63.77 \mathrm{mg} / \mathrm{kg}$, Or-P 12.73 $\mathrm{mg} / \mathrm{kg}$ and TP $76.49 \mathrm{mg} / \mathrm{kg}$, accounted for the $75.51 \%$, $7.86 \%, 83.37 \%, 16.63 \%$ and $100 \%$ of TP respectively. It is clear that the sediments are mainly composed by inorganic phosphorus, and the inorganic phosphorus mainly contains $\mathrm{NaOH}-\mathrm{P}$ component, suggesting that the agricultural water body pollution is serious [15].

\subsection{Experimental Methods}

\subsubsection{PH and Rule of Phosphorus Migration Transformation}

$15 \mathrm{~g}$ previous processed samples and $200 \mathrm{ml}$ deionized water were added in each of $18300 \mathrm{~mL}$ absorption bottles. The bottles were divided into both Group A and B. Group A was sterilized $30 \mathrm{~min}$. Group $\mathrm{A}$ and $\mathrm{B}$ were divided into 3 subgroups each, in which $\mathrm{NaOH}$ and $\mathrm{HCl}$ solution was added to regulate $\mathrm{pH}$ to 5,7 and 9.18 samples were sealed and placed in a shaker $(25 \pm 0.5)^{\circ} \mathrm{C}$ and oscillated at $150-160$ $\mathrm{r} / \mathrm{min}$. The experimental time was 30 days. The samples were collected from overlying water in predetermined period to analyze. A stable $\mathrm{pH}$ was maintained in each bottle during the experiment. Final distribution of phosphorus forms in the sample was determined after completion of the experiment.

\subsubsection{Dissolved Oxygen and Rule of Phosphorus Migration and Transformation}

$300 \mathrm{~g}$ previous processed sample was gently laid in a $1000 \mathrm{~mL}$ tall beaker, and $750 \mathrm{~mL}$ deionized water was added in mud-water height ratio about 1:5. The sample was cultured in a constant temperature incubator culture $\left(25^{\circ} \mathrm{C}\right)$. During the culture, dark time and sunshine time were 12 hours a day separately. The sample was divided into 2 groups (anaerobic and aerobic), each group included 3 parallel sub-samples and all were put under a sealed state. The air was aerated daily under the aerobic conditions and the nitrogen (at purity 99\%) was aerated daily under the anaerobic conditions about $2 \mathrm{~h}$ (in such an amount that the 
bottom mud does not overflow upwards). The sample was sealed with plastic film to prevent against the contact and circulation between air and overlying water. Samples were taken from overlying water to analyze DO and DTP in a period 30 days. Final distribution of phosphorus forms in the sample was determined after completion of the experiment.

\subsubsection{Sunlight and Rule of Phosphorus Migration and Transformation}

$15 \mathrm{~g}$ previous processed sample was gently laid in a 500 $\mathrm{mL}$ tall beaker and $200 \mathrm{~mL}$ deionized water was added in a mud-water height ratio about 1:2. The samples were tested separately under sunlight-free illumination $\left(\begin{array}{ll}0 & \mathrm{~lx}\end{array}\right)$, low illumination (3000 lx) and high illumination (6000 lx). 3 repeated experiments were done in each illumination. The sunlight time and sunlight-free time were 12 hours each. During the experiment, the beaker is mount-open so the overlying water is contacted and circulated with the air. The experimental temperature was controlled at $25^{\circ} \mathrm{C}$ for continuously $30 \mathrm{~d}$. Samples were taken from overlying water regularly. The beaker was wrapped with black card-paper tightly for the sunlight-free group. Final distribution of phosphorus forms in the sample was determined after completion of the experiment.

\section{RESULTS AND DISCUSSION}

\subsection{PH and Phosphorus Migration and Transformation}

As illustrated in Figs. $(\mathbf{2}, \mathbf{3})$, DTP in overlying water is at minimum in a neutral state, $\mathrm{pH}$ rise or fall will cause the increase of phosphorus concentration in overlying water, however, $\mathrm{pH}$ rise is prone to increase the phosphorus concentration in overlying water, namely $\mathrm{pH}$ increase will facilitate the phosphorus migration and transformation from soil to water. The phosphorus in sediments will migrate to water regardless of acidic, neutral or alkaline state of sediments. The NaOH-P (Fe/Al-P) migrates in a best significant way at alkaline state whilst $\mathrm{HCl}-\mathrm{P}(\mathrm{Ca}-\mathrm{P})$ is prone to migrate in acidic conditions. The results agreed with findings of Gao Li, et al. [16-18].

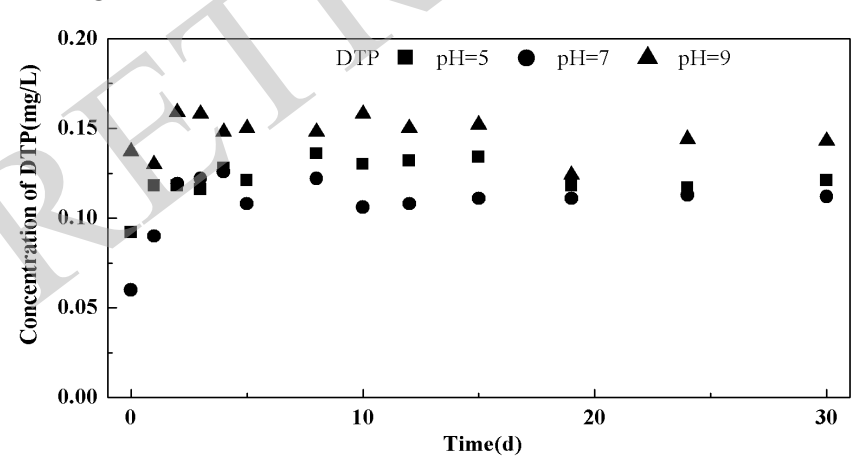

Fig. (2). Influence of $\mathrm{pH}$ on phosphorus concentration in overlying water.

XPS characterization of sediments before and after experiment further proofs the above phenomenon (Figs. 4, 5). The narrow scan spectrum on surface $F e(2 p)$ before phosphorus release in sediments shows the binding energy of surface $\mathrm{Fe}(2 \mathrm{p})$ is $711.41 \mathrm{ev}$. Based on XPS chemical-state database, it is suggested that the main object phase of surfaceiron is $\mathrm{Fe}_{2} \mathrm{O}_{3}$; the binding energy of surface

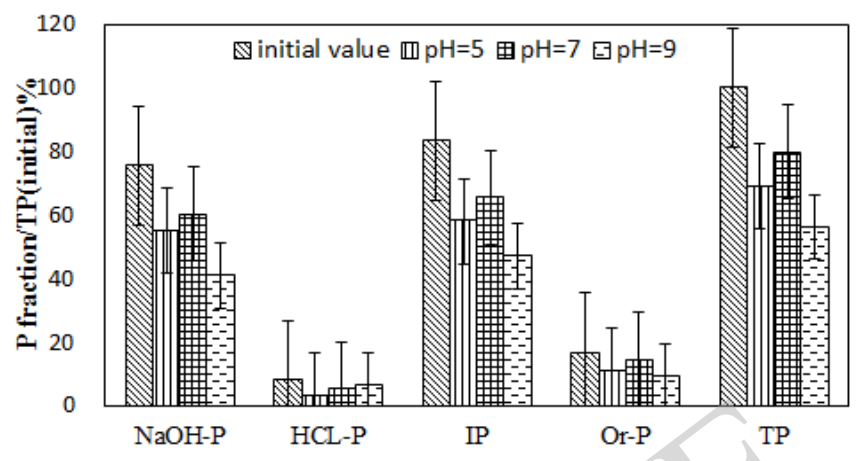

Fig. (3). Migration and transformation of phosphorus forms in ditch sediments in original state and at different $\mathrm{pH}$ values (\%).

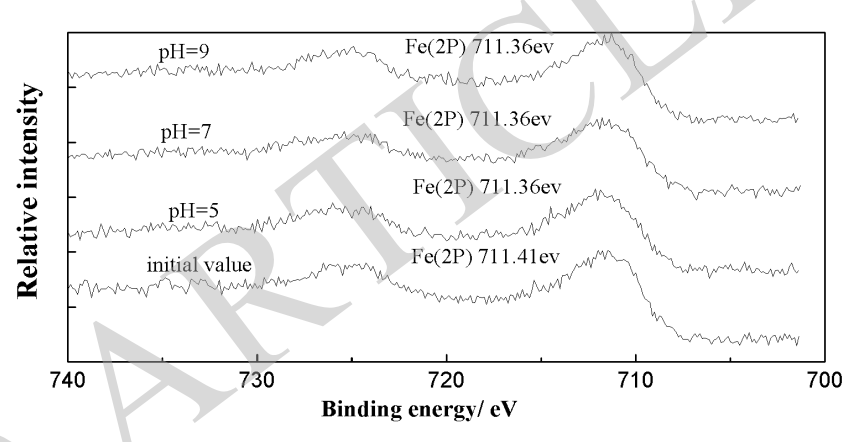

Fig. (4). Fe (2p) binding energy at different $\mathrm{pH}$ value.

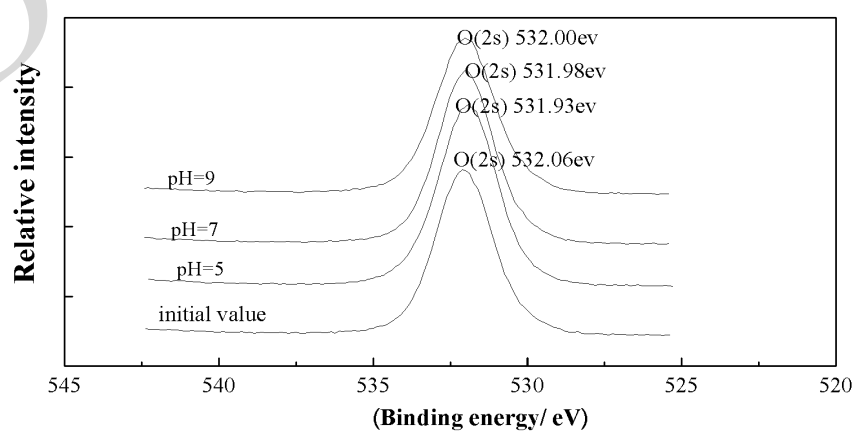

Fig. (5). $\mathrm{O}(1 \mathrm{~s})$ binding energy at different $\mathrm{pH}$ value.

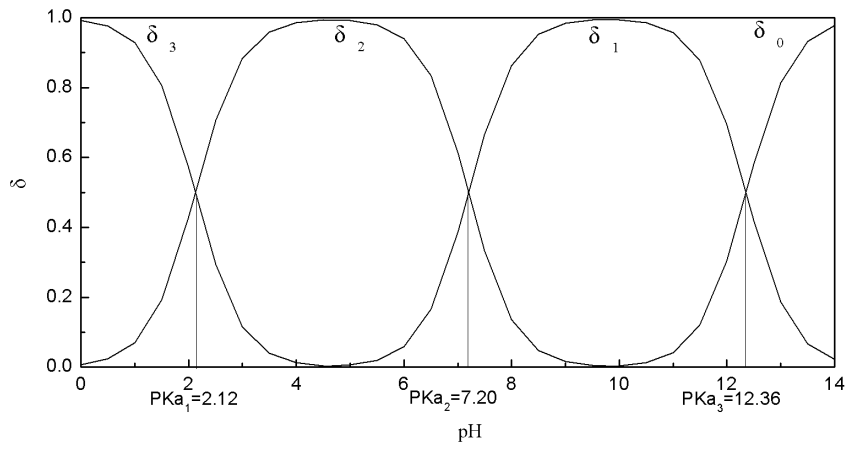

Fig. (6). The relationship between the four forms of phosphate distribution coefficients and the $\mathrm{pH}$.

Fe (2p) is all $711.36 \mathrm{ev}$ after the sediment releases the phosphorus under all $\mathrm{pH}$ conditions, and does not change comparing to the findings prior to experiment. It is clear from the relationship deduced by Ding [19] between the Fe 
energy charge level and the binding energy that the surface charge of iron atom has almost not changed. From the relationship constructed by Jong [20] between $\mathrm{O}(1 \mathrm{~s})$ binding energy and surface charge, the surface charge calculated on the oxygen atoms has almost not changed as well (the binding energy of sediments before and after experiment are $532.06 \mathrm{ev}, 531.93 \mathrm{ev}, 531.98 \mathrm{ev}$ and $532.00 \mathrm{ev}$ respectively), namely, they change in an identical trend, suggesting that no electron transfer occurs insignificantly during the process of phosphorus release in sediments, i.e. no electron transfer reaction occurs on surface. This further proofs that the phosphorus absorption form $\mathrm{HPO}_{4}{ }^{2-}$ in sediment substitutes $\mathrm{OH}$ state on the sediment surface. According to Fig. (6), the free $\mathrm{OH}^{-}$in the solution is high in the concentration under the alkaline conditions, which is prone to compete for absorption with phosphate anions bound by $\mathrm{Fe}^{3+}, \mathrm{Al}^{3+}$, etc. Eventually $\mathrm{Fe}^{3+}$ and $\mathrm{Al}^{3+}$ in sediments are transformed to more stable hydroxyl compound. Phosphates binding to $\mathrm{Fe}^{3+}$ and $\mathrm{Al}^{3+}$ migrate to water due to the ion exchange so that the phosphorus concentration rises in water solution [21-23]. After computing, Fig. (3) also shows that the reduced $\mathrm{NaOH}-\mathrm{P}$ amount is up to $49 \%, 31 \%$ upwards of HCl-P $18 \%$. Contrarily, the reduced HCl-P amount is up to $39 \%$ under the acid state, $11 \%$ upwards of $\mathrm{NaOH}-\mathrm{P} 28 \%$, suggesting the increasing $\mathrm{pH}$ produces a larger influence on phosphorus migration and transformation, the alkaline state is beneficial for $\mathrm{NaOH}-\mathrm{P}$ migration to water and the acidic state is beneficial for HCL-P migration to the water. The reasons may be (1) The ratio of NaOH-P to HCl-P is up to 9.61 in original sedimentary soil; (2) The phosphorus migration and transformation in sediments and water are subject to the phosphate solubility in the case of smaller $\mathrm{pH}$. The calcium phosphate increases in solubility, thus leasing to the phosphorus migration to water better $[16,23]$.

\subsection{Dissolved Oxygen and Phosphorus Migration and Transformation}

The rules derived under the aerobic and anoxic experiments are the same as the previous study results, namely, the hypoxic environment facilitates migration from the overlying water to sediments and aerobic environment does in an opposite manner [24].

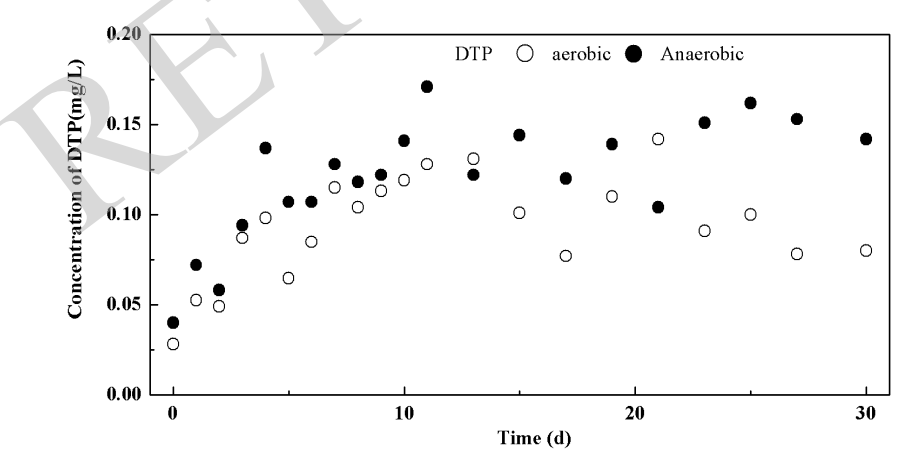

Fig. (7). Dissolved oxygen (DO) influence on phosphorus migration and transformation in the overlying water.

Fig. (7) shows that the DTP concentrations in overlying water under the aerobic state are lower than under anaerobic state.

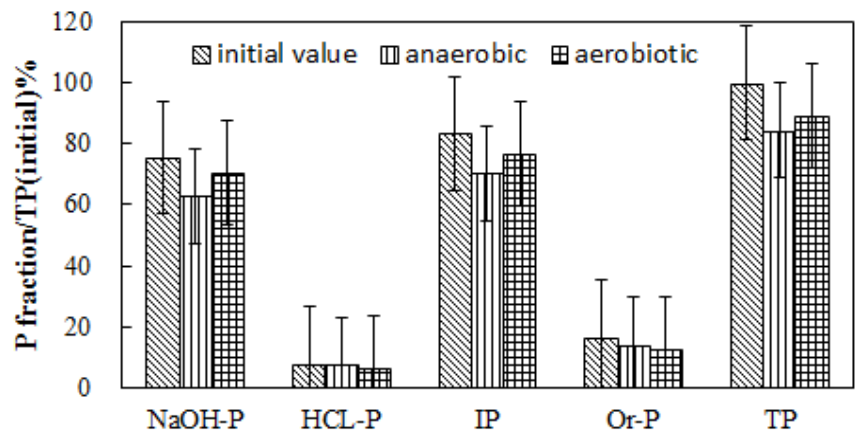

Fig. (8). Mgration and transformation of phosphorus forms in ditch sediments under differential state (\%).

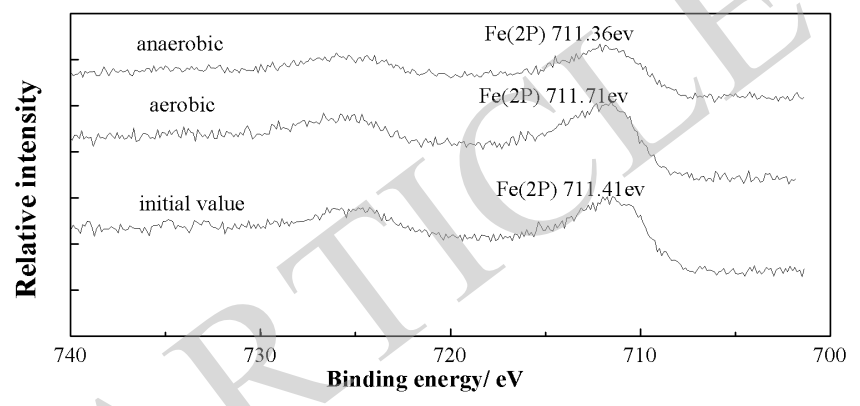

Fig. (9). Fe (2p) binding energy at different state.

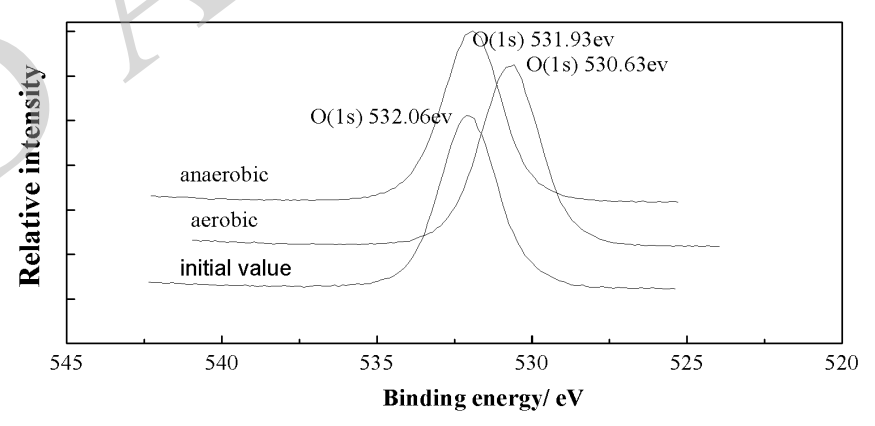

Fig. (10). O (1s) binding energy at different state.

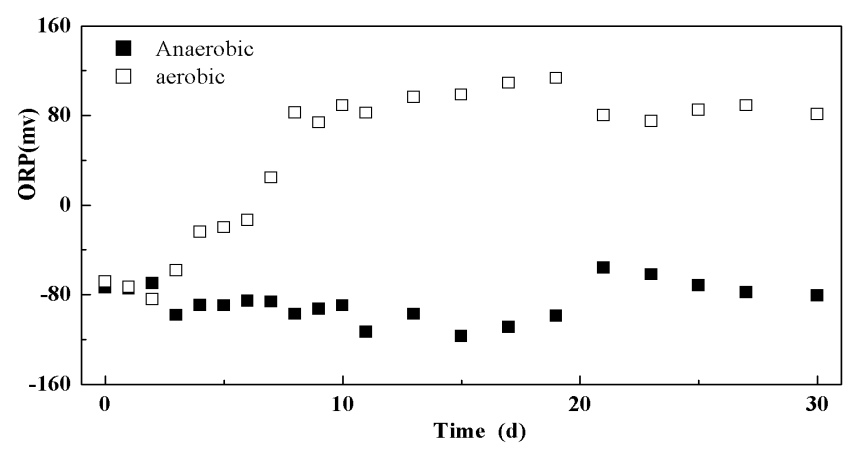

Fig. (11). Change rule of ORP in overlying water.

Fig. (8) shows NaOH-P in sediments decreases under anaerobic and aerobic conditions, but it releases significantly under anaerobic conditions, whilst HCl-P and Or-P decrease more under aerobic conditions. Fig. (8) also shows $\mathrm{NaOH}-\mathrm{P}$ is the main source of phosphorus release, which is agreed with what was derived by Wang Shengrui et al. [25]. XPS characterization data in sediments before and after the experiment is agreed with the above conclusion. The narrow 
scan spectrum on its surface Fe $(2 p)$ shows that the binding energy on surfaces Fe (2p) is $711.41 \mathrm{ev}$ and $711.71 \mathrm{ev}$ respectively whilst the binding energy on $\mathrm{O}(1 \mathrm{~s})$ is 532.06 ev and $530.63 \mathrm{ev}$ before and after aeration respectively. The binding energy on surface Fe $(2 p)$ and $\mathrm{O}(1 \mathrm{~s})$ after nitrogen aeration is $711.36 \mathrm{ev}$ and $531.93 \mathrm{ev}$ respectively. Similarly, computing by the model $[19,20]$, it is clear that the surface charge of iron after oxygen aeration reduces, the surface charge of oxygen increases, suggesting that the electron transfer occurs on the sediment during aeration, namely, the oxidation-reduction reaction occurs on the surface. No electron transfer occurs before and after nitrogen aeration, namely, no redox reaction occurs.

\subsection{Sunlight and Phosphorus Migration and Transformation}

\subsubsection{PH and ORP (Oxidation-Reduction Potential) Change Rule in Overlying Water}

Fig. (12) shows that $\mathrm{pH}$ changes significantly in overlying water in sunlight group, but the illumination is correlated to the $\mathrm{pH}$ value insignificantly. The $\mathrm{pH}$ keeps at $6.5 \sim 7.0$ in initial $5 \mathrm{~d}$ and then starts to rise. Because algae growth in the sunlight group, $\mathrm{CO}_{2}$ is absorbed, the oxygen is released and the change of $\mathrm{pH}$ is significantly higher than sunlight-free group. The presence of algae cell can be observed microscopically. The $\mathrm{pH}$ whenever under sunlight or sunlight-free groups, the $\mathrm{pH}$ reaches a turning point at the $21^{\text {st }}$ day and then gradually stabilizes. The $\mathrm{pH}$ in the sunlight group increases to 8.3 around (alkaline), while the maximal $\mathrm{pH}$ is only 7.1 in the sunlight-free group.

The change of DO is similar to $\mathrm{pH}$ under different sunlight conditions. Fig. (13) shows that the DO changes significantly in overlying water in sunlight group, but the illumination is correlated to DO insignificantly. It keeps at $0.1-0.8 \mathrm{mg} / \mathrm{L}$ in initial $5 \mathrm{~d}$ and then starts to rise. The increased DO in sunlight group is significantly higher than sunlight-free group. The DO in the sunlight group reaches a turning point at the $21^{\text {st }}$ day and then gradually stabilizes whilst DO in sunlight-free does not change obviously. The DO in sunlight group increases to $8.3 \mathrm{mg} / \mathrm{L}$ around and is 7 $\mathrm{mg} / \mathrm{L}$ in sunlight-free group at the end of experiment.

The above results show that illumination affects the dissolved oxygen concentration by affecting biological processes, and ultimately affect the change of $\mathrm{pH}$ and DO in the overlying water [26]. Under the presence of sunlight, the $\mathrm{pH}$ and DO in the overlying water will increase. The equation is specified as follows:

$$
\mathrm{CO}_{2}+\mathrm{H}_{2} \mathrm{O} \stackrel{\text { Ilumin ance\& chlorphyll }}{\longrightarrow}\left[\mathrm{CH}_{2} \mathrm{O}\right]+\mathrm{O}_{2}
$$

Due to the immaturity of the interfaced benthic algal communities during the early experimental period, $\mathrm{pH}$ is at 6.5 7.0, whilst DO maintains at $0.1-1.0 \mathrm{mg} / \mathrm{L}$. Under sunlight conditions, the algae thrive in the photosynthesis gradually and cause the significant rise of DO. At about 21 $\mathrm{d}$, the biological growth under sunlight conditions reaches a peak, the interfaced communities are at a dynamic equilibrium, and the $\mathrm{pH}$ and $\mathrm{DO}$ are thus stabilized. However, Figs. $(\mathbf{1 2}, \mathbf{1 3})$ also show the effect of illumination does not a significant rule on the $\mathrm{pH}$ and $\mathrm{DO}$, suggesting that there are a plurality of algae in the ecosystems under the study whilst the saturated light intensity is different as required by the maximum specific growth rate in different algae $[27,28]$.

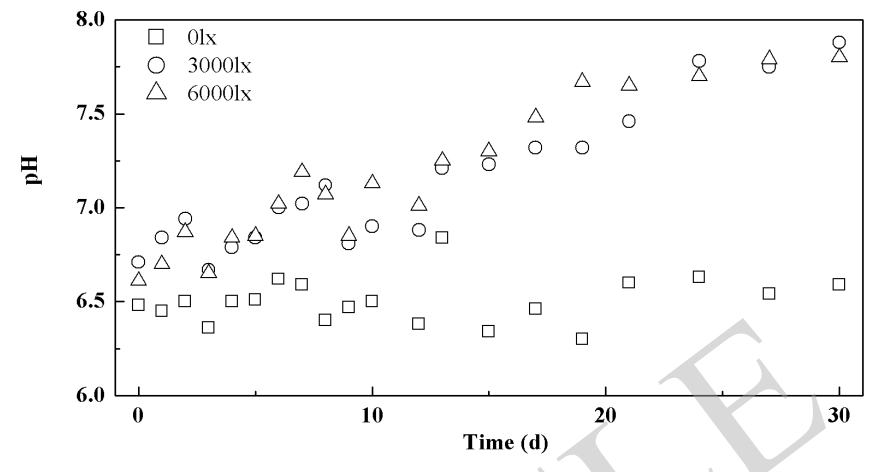

Fig. (12). Change of $\mathrm{pH}$ in overlying water.

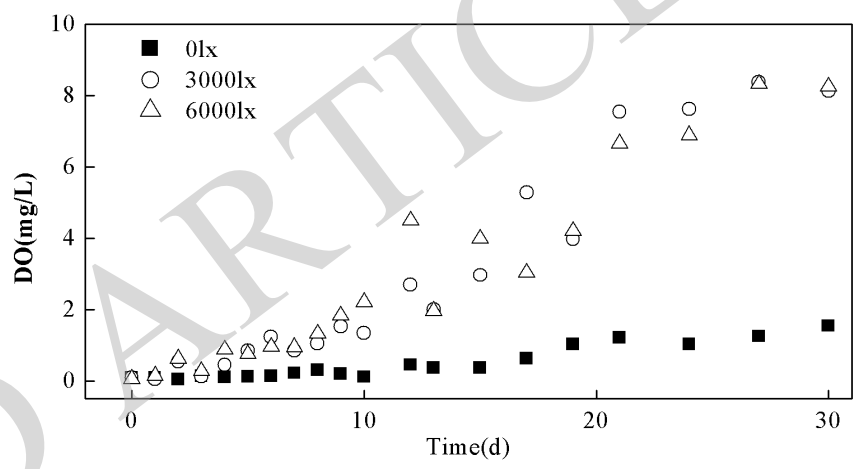

Fig. (13). Change of DO in overlying water.

\subsubsection{Sunlight and Phosphorus Migration and Transformation}

Figs. $(14,15)$ show that the amount of phosphorus migration and transformation to the overlying water in the sunlight group is generally lower than the sunlight-free group.

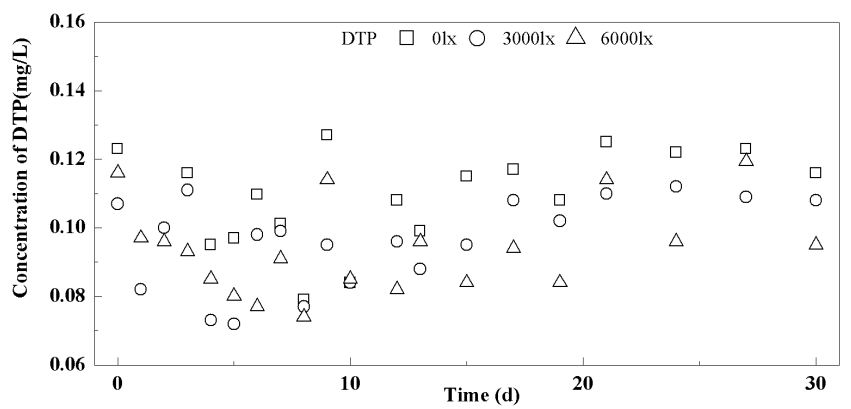

Fig. (14). Influence of sunlight on the phosphorus concentration in the overlying water.

XPS data from Figs. (16, 17) show that the binding energy on sediments surface Fe (2p) is $711.41 \mathrm{ev}, 711.71 \mathrm{ev}$, $711.72 \mathrm{ev}$ and $711.70 \mathrm{ev}$ respectively whilst the binding energy on $\mathrm{O}(1 \mathrm{~s})$ is $532.06 \mathrm{ev}, 531.98 \mathrm{ev}, 530.507 \mathrm{ev}$ and $530.591 \mathrm{ev}$ respectively before and after the experiment. Computing by the model $[19,20]$ gives that the surface charge of iron reduces under the sunlight action, the surface charge of oxygen increases, suggesting that the electron transfer occurs on the sediment during sunlight action 
significantly, namely, the oxidation-reduction reaction occurs on the surface. But it is correlated to the illumination insignificantly. No electron transfer occurs under $01 \mathrm{x}$ illumination, namely, no redox reaction occurs. This finding is agreed with above conclusion. That is, the illumination affects NaOH-P transformation indirectly by changing $\mathrm{pH}$ and DO [29] mainly affected by biological process. Due to this reason, the phosphorus assimilation by algae is not appropriate to the corresponding relation between algae proliferation and sunlight intensity in Figs. (14, 17). Based on the conclusion in $\mathrm{pH}$ and $\mathrm{DO}$ change rule in overlying water, this will be conducive to phosphorus migration and transformation from sediments to the water. However, Figs. $(14,15)$ show that the phosphorus concentration in the overlying water under sunlight condition is not higher than under the sunlight-free group. It is obvious that the biological effect may equal or surpass the $\mathrm{pH}$ influence. The specific mechanism remains to be further research.

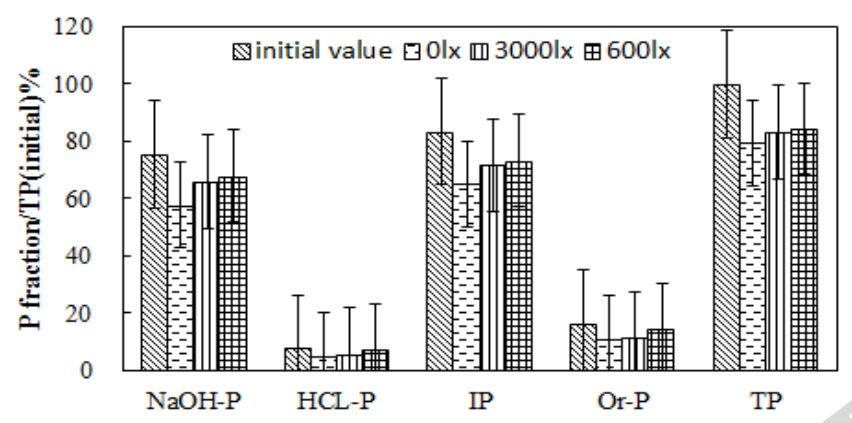

Fig. (15). Rule of migration and transformation of phosphorus forms in original state and under different sunlight intensity (\%).

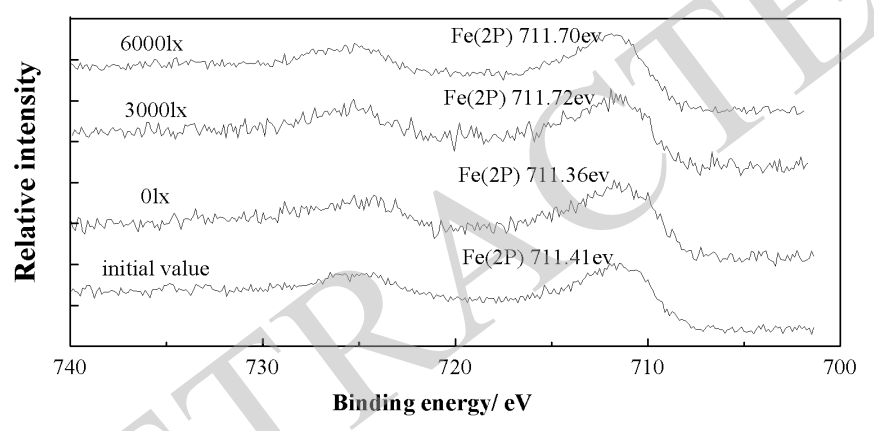

Fig. (16). $\mathrm{Fe}(2 \mathrm{p})$ binding energy at different sunlight intensity.

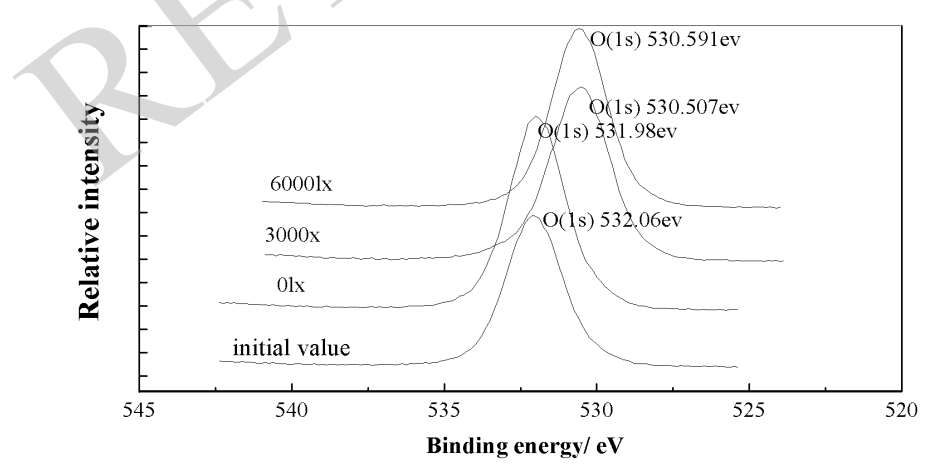

Fig. (17). O (1s) binding energy at different sunlight intensity.

HCl-P and Or-P is far more vulnerable to the biological effects than NaOH-P because Zhou Yiyong [30] et al. found that the mineralized phosphorus can be effectively dissolved in organic acid synthesis in microbes. The large number of strains that can produce organic acids and gluconic acid are the typical medium. The organic phosphorus mineralization is also an acting process of phosphatase. All organisms in the water can produce the phosphatase as the greatest contribution is made by bacteria, phytoplankton and zooplankton [31]. Therefore, the organophosphorus and $\mathrm{HCl}-\mathrm{P}$ decreased more significantly in sunlight group. But the illumination is correlated with the released phosphorus insignificantly, thus further proofing the presence of different algae systems. The phosphorus assimilation by algae is not appropriate to the corresponding relation between algae proliferation and sunlight intensity. This finding is agreed with the previous studies on phosphorus release.

\section{CONCLUSION AND RECOMMENDATIONS}

The sediment is composed mainly of inorganic phosphorus that includes NaOH-P component majorly, suggesting that the agricultural water pollution is more serious.

Many researchers has studied the process of phosphorus release of sediment influenced by $\mathrm{pH}$, DO, light, but the existence of electron transfer phenomenon is to be revealed by XPS binding energy data combined with phosphorus migration process rarely. In order to reveal the migration of phosphorus into the essence, XPS binding energy data is unified with phosphorus migration process. The results are as follows.

The influence of $\mathrm{pH}$ migration and transformation in sediments varies with the phosphorus forms. The ditch sediments in the study can cause the rise of phosphorus concentration whenever at acidic or alkaline state, but the amount is more under the alkaline state. There is no electron transfer occurs insignificantly at different $\mathrm{pH}$ values in sediments, the phosphorus absorption form $\mathrm{HPO}_{4}{ }^{2-}$ in sediment substitutes $\mathrm{OH}^{-}$state on the sediment surface.

When oxygenated, the oxidation-reduction reaction occurs on the sediment surface, $\mathrm{Fe}^{2+}$ is oxidized into $\mathrm{Fe}^{3+}$ under aerobic atmosphere, the absorbed phosphorus increases. Under anaerobic atmosphere, the phosphorus in sediments is prone to migrate to the water.

The illumination affects NaOH-P transformation indirectly by changing $\mathrm{pH}$ and $\mathrm{DO}$ mainly affected by biological process. The electron transfer occurs on the sediment during sunlight action significantly, namely, the oxidation-reduction reaction occurs on the surface. But the illumination is correlated to the phosphorus migration and transformation in the sediments insignificantly. Conclusively, the migrated and transformed phosphorus in sunlight-free group is greater than the sunlight group.

Based on these conclusions, it is recommended the aquatic plants, especially submerged plants, must be grown in field ditches. This will not only be beneficial to oxygen recovery, but also lower the $\mathrm{pH}$ in the overlying water without any hindrance to the sunlight. However, the attention should be paid to the planting density and regular harvesting. 
In this paper, there are still some limitations. Mainly, the factors of temperature and flow rate are not taken into account, and the effects of various factors are not independent of each other, but intercrossed. Therefore, the further studies must explore the other factors, compute the contribution rate of each factor and finally determine the predominant factor.

\section{CONFLICT OF INTEREST}

The authors declared that they have no conflict of interest to this work.

\section{ACKNOWLEDGEMENTS}

This work was supported by Scientific Research Fund in the 2012 year of Jiangxi Provincial Education Development (GJJ12433), the Science and Technology Planning Projects of Jiangxi Province (20122BBG70079), the Natural Science Foundation of Jiangxi Province (20114BAB203022) and National Natural Science Foundation of China (41261097).

\section{REFERENCES}

[1] J. M. Li, X. M. Zhao, J. Zhang, and X. Guo, "Agricultural Resources Zoning in Poyang Lake Region of Jiangxi Province", Acta Agriculturae Universitatis Jiangxiensis, vol. 33, pp. 12521256, December 2011

[2] C. X. Xu, C. R. Peng, Z. G. Ye, X. M. Chen, W. D. Liu, and Q. P. $\mathrm{Su}$, "Effect of the Fertilization Model of N Controlling and P Saving on Nutrient Uptake and Rice Yield", Chinese Journal of Agroneteorology, vol. 31 (S1), pp. 53-56, December 2010.

[3] W. J. Schoumans, M. E. Chardon, C. Bechmann, G. GascuelOdoux, B. Hofman, G. H. Kronvang, B. Rubæk, J.M. Ulén, and Dorioz, "Mitigation options to reduce phosphorus losses from the agricultural sector and improve surface water quality: A review", Science of the Total Environment, vol. 468/469, pp. 1255-1266. June 2014.

[4] L. Ahiablame, I. Chaubey, and D. Smith, "Nutrient content at the sediment-water interface of tile-fed agricultural drainage ditches", Water, vol. 2, pp. 411-428, August 2010.

[5] I. Herzon, and J. Helenius, "Agricultural drainage ditches, their biological impor-tance and functioning", Biol. Conserv. vol. 141, pp. 1171-1183, March 2008.

[6] L. H. Zhai, H. L. Liu, B. D. Xi, and H. D. Xu, "Study on the transportation and trans-formation of $\mathrm{N}$ and $\mathrm{P}$ in headwater ditches", Res. Environ. Sci, vol. 21, pp. 35-39, February 2008.

[7] D. Bhattacharya and S. Roychowdhury, "A Constrained Cost Minimizing Redundancy Allocation Problem in Coherent Systems with Non-overlapping Subsystems", Advances in Industrial Engineering and Management, vol. 3 no. 3, pp. 1-6, 2014. doi:10.7508/AIEM-V3-N3-1-6

[8] D. F. Fu, W. J. Gong, Y. Xu, Rajendra Prasad Singh, Y. Rao Surampalli, and T.C. Zhang, "Nutrient mitigation capacity of agricultural drainage ditches in Tailake basin", Ecological Engineering, vol. 71, pp. 101-107, August 2014.

[9] V. Pardeshi, "m-Governance: Next Frontier in Governance from Indian Context", Advances in Industrial Engineering and Management, vol. 3 no. 2, pp. 5-12, 2014. doi:10.7508/AIEM-V3$\mathrm{N} 2-5-12$

[10] W. Liu, Z. L. Chen, J. Wang, J. Zhang, C. X. Yao, and L. N. Li, "Cycling Characters of Phosphorus between Water and Sediment of River from a Small Town", Journal of Agro-Environment Science, vol. 23, pp. 272, August 2004.

[11] Lee-Hyung Kim, Euiso Choi, and Michael K Stenstrom, "Sediment characteristics, phosphorus types and phosphorus release rates between river and lake sediments", Chemosphere, vol. 50, pp.53-61, January 2003.
[12] Q. Zhang, "Shift of phosphorus sink-source functions of constructed wetlands and a theoretical explanation", Journal of Lake Sciences, vol. 19, pp. 46-51, March 2007.

[13] ASTM, "Standard Guide for Collection, Storage, Characterization, and Manipulation of Sediments for Toxicological Testing. American Society for Testing and Materials, Philadelphia, PA.; Wentworth, C.K. (1922) A scale of grade and class terms for classic sediments", Journal of Geology, vol. 30, pp. 377-394, 1991.

[14] V. Ruban, J. F. Lo'pez-Sa'nchez, P. Pardo, G. Rauret, H. Muntau, and Quevauviller Ph, "Harmonized protocol and certified reference material for the determination of extractable contents of phosphorus in freshwater sediments-A synthesis of recent works", Fresenius J Anal Chem, vol. 370, pp. 224-8, June 2001.

[15] Q. H. Huang, Z. J. Wang, C. X. Wang, S. R. Wang, and X. C. Jin, "Phosphorus Release in Response to $\mathrm{pH}$ Variation in the Lake Sediment with Different Ratios of Iron-Bound P to Calcium-Bound P", Chemical Speciation and Bioavailability, vol. 17, pp. 55-61, April 2005.

[16] L. Gao, "Phosphorus release from the sediments in Rongcheng Swan Lake under different pH condition", Procedia Environmental sciences, vol. 13, pp. 2077-2084, February 2012.

[17] Z. Y. Guo, X. C. Li, C. Wang, and H. T. Ma, "Influence of $\mathrm{pH}$ Value on the Release and the Chemical Fractions of Phosphorus in Sediments of Xuanwu Lake", Journal of Agro-Environment Science, vol. 26, pp. 873-877, May 2007.

[18] X. C. Jin, X. Jiang, Y. Yao, L. H. Li, and F. C. Wu, "Effects of light and oxygen on the uptake and distribution of phosphorus at the sediment-water interface", Science of the Total Environment, vol. 357, pp. 231-236, February 2006.

[19] M. Ding, B. H. Jong, and S.J. Roosendaal, "XPS studies on the electronic structure of bonding between solid and solutes: Adsorption of arsenate, chromate, phosphate, $\mathrm{Pb}^{2+}$ and $\mathrm{Zn}^{2+}$ ions on amorphous black ferric oxyhydroxide", Geochimica et Cosmochimica Acta, vol. 64, pp. 1209-1219, August 2000.

B. H. Jong, D, Ellerbroek, and A. L. Spek, "Low temperature structure of lithium nesosilicate, $\mathrm{Li}_{4} \mathrm{SiO}_{4}$, and its $\mathrm{Li} 1 \mathrm{~s}$ and $\mathrm{O} 1 \mathrm{~s} \mathrm{X}$ ray photoelectron spectrum", Acta Cryst (B), vol. 50, pp. 511-518, October 1994.

[21] L. Lijklema, "The role of iron in the exchange of phosphorus between water and sediments. In: Golterman, H.L. (Ed.), Interactions between Sediments and Freshwater, Dr W. Junk", The Hague, pp. 313-317, 1977.

[22] B. M. Boström, Jansson, and C. Forsberg, "Phosphorus release from lake sediments", Archiv für Hydrobiologie-Beiheft Ergebnisse der Limnologie, vol. 18, pp. 55-59, April 1982.

[23] S. R. Wang, H. C. Zhao, S. W. Yang, and W. L. Yi, "Effect of Different Type Sediments on Transformation of Phosphorus Forms and Growth of Myriophyllum spicatum", Environmental Science, vol. 31, pp. 2666-2672, November 2010

[24] E. Gomez, C. Durillon, and G. Rofes G, "Phosphate adsorption and release from sediments of brackish lagoons: $\mathrm{pH}, \mathrm{O}_{2}$ and loading influence", Water Research, vol. 33, pp. 2437- 2447, October 1999.

[25] S. R. Wang, X. C. Jin, Q. Y. Bu, L. X. Jiao, and F. C. Wu, "Effects of dissolved oxygen supply level on phosphorus release from lake sediments", Colloids and Surfaces A: Physicochem. Eng. Aspects, vol. 316, pp. 245-252, April 2008.

[26] X. C. Jin, S. R. Wang, Y. Pang, and F. C. Wu, "Phosphorus fractions and the effect of $\mathrm{pH}$ on the phosphorus release of the sediments from different trophic areas in the Taihu Lake, China", Environ. Pollut, vol. 139, pp. 288-295, February 2006.

[27] Q. Liu, X. F. Ziang, T. W. Li, and X. R. Su, "Effects of light on growth rate chlorophyll level and cell cycle in four alga species", Journal of Dalian Fishery University, vol. 21, pp. 24-30, January 2006.

[28] Y. Yin, Y.L. Zhang, M.Z. Wang, X.H. Liu, and Z.Q. Shi, "Effects of different irradiation intensity on the growth and absorption properties of Microcystis aeruginosa and Scenedesmus obliqnus", Journal of Lake Sciences, vol. 24, pp. 755-764, October 2012.

[29] K.G. Taylor, C.T. Perry, A.M. Greenaway, and P.G. Machent, "Bacterial iron oxide reduction in a terrigenous sediment-impacted tropical shallow marine carbonate system, north Jamaica", Marine Chemistry, vol. 107, pp. 449-463, December 2007. 
[30] Y.Y. Zhou, J.Q. Li, and M. Zhang, "Temporal and spatial variations in kinetics of alkaline phosphatase in sediments of a shallow Chinese eutrophic lake (Lake Donghu)", Water Research, vol. 36, pp. 2084-2090, April 2002.
[31] N. Jean, G. Boge, J. Jamet, S. Richard, and D. Jamet, "Seasonal changes in zooplanktonic alkaline phosphatase activity in Toulon Bay (France): the role of Cypris larvae", Marine Pollution Bulletin, vol. 46, pp. 346-352, March 2003.

(C) Tang et al.; Licensee Bentham Open.

This is an open access article licensed under the terms of the (https://creativecommons.org/licenses/by/4.0/legalcode), which permits unrestricted, noncommercial use, distribution and reproduction in any medium, provided the work is properly cited. 